\title{
Osteoarticular Involvement and Inadequate Treatment of Brucellosis are Related to Relapse
}

\author{
Brusellozda Osteoartiküler Organ Tutulumu ve Yetersiz Tedavinin Relaps ile Illişkisi
}

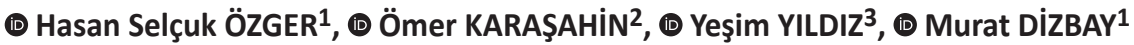 \\ ${ }_{1}^{1}$ Gazi University Faculty of Medicine Hospital, Department of Infectious Diseases and Clinical Microbiology, Ankara, Turkey \\ 2Erzurum Regional Training and Research Hospital,Clinic of Infectious Diseases and Clinical Microbiology, Erzurum, Turkey \\ ${ }_{3}^{3}$ Mardin State Hospital, Clinic of Infectious Diseases and Clinical Microbiology, Mardin, Turkey
}

\section{Abstract}

Introduction: The goal of treatment in brucellosis is to control symptoms to prevent the development of complications and relapse of infection. The aim of this study was to evaluate the risk factors for relapse in brucellosis patients, including those with complications.

Materials and Methods: Our study was performed retrospectively with data from three centers. Complication of brucellosis was defined as the involvement of specific anatomical regions in the disease. Recurrence of symptoms and signs of brucellosis six months after termination of treatment and increased standard tube agglutination titer under treatment or isolation of Brucella spp. in sterile body fluids was defined as relapse. Inadequate treatment duration was defined as a treatment duration of less than eight weeks in patients with osteoarticular complications and less than six weeks in other brucellosis involvement. A multivariate logistic regression model was built with the variables determined to be effective in relapse development. The logistic regression model included gender, the presence of osteoarticular complications, inadequate treatment duration, treatment combinations, and leukocyte count. The SPSS 20 statistical package program was used for statistical analysis.

Results: A total of 1,296 patients were enrolled in the study. Their median age was 42 (31-54) years and 631 (48.7\%) were female. One or more complications were detected in $448(34.6 \%)$ cases. A two-drug antibiotic combination was given to 1,125 (86.8\%) patients and 171 (13.2\%) were treated with a three-drug antibiotic combination regimen. Three hundred sixteen (24.4\%) of the patients were treated with combination therapies that included an aminoglycoside. Relapse occurred in 110 (8.5\%) patients, and treatment was inadequate for 105 (8.1\%) cases. Osteoarticular complications were more frequent in patients with relapse than in those without relapse $(33.6 \%$ vs $18.5 \%$, $p<0.001)$. The presence of osteoarticular complications [odds ratio (OR): 2.413, 95\% confidence interval (Cl): 1.550-3.756] and inadequate treatment duration (OR: 2.861, 95\% Cl: 1.6454.974) were associated with a higher rate of brucellosis relapse, while combination therapies including an aminoglycoside (OR: $0.432,95 \% \mathrm{Cl}$ : 0.249-0.752) was associated witha lower relapse rate.

Conclusion: Our results indicate that in patients with osteoarticular complications, treatment should be administered for the recommended optimal duration, and combination therapies including aminoglycosides should be chosen preferentially in order to prevent a relapse of infection.

Keywords: Inadequate treatment, brucellosis, osteoarticular involvement, relapse

\section{Öz}

Giriş: Brusellozda tedavinin amacı semptomları kontrol etmek, komplikasyon gelişimini ve tekrarlayan enfeksiyonları önlemektir. Bu çalışmanın amacı, bruselloz hastalarında komplikasyon olanlar da dahil olmak üzere relaps için risk faktörlerini değerlendirmektir.

Gereç ve Yöntem: Çalışmamız retrospektif olarak üç merkezden alınan verilerle yapıldı. Bruselloz komplikasyonu, spesifik anatomik bölgelerin tutulumu olarak tanımlandı. Bruselloz ile ilişkili semptom ve bulguların tedavinin sonlandırılmasından altı ay sonra tekrarlaması ve tedavi altında artmış standart tüp aglütinasyon titresi veya steril vücut sıvılarında Brucella spp. izolasyonu relaps olarak tanımlandı. Yetersiz tedavi süresi osteoartiküler komplikasyon saptanan olgularda sekiz hafta altında, diğer bruselloz olgularında ise altı hafta altında tedavi olarak tanımlandı. Nüks geliş̧iminde etkili olduğu belirlenen değişkenlerle bir "multivariate" lojistik regresyon modeli oluşturuldu. Lojistik regresyon modeline cinsiyet, osteoartiküler komplikasyon varlığı, tedavi süresi uygunsuzluğu, tedavi kombinasyonları ve lökosit sayısı dahil edildi. İstatistiksel analiz için SPSS 20 istatistik paket programı kullanıldı.

Cite this article as: Özger HS, Karaşahin Ö, Yıldız Y, Dizbay M. Osteoarticular Involvement and Inadequate Treatment of Brucellosis are Related to Relapse. Mediterr J Infect Microb Antimicrob. 2020;9:1. 
Bulgular: Toplam 1.296 hasta çalışmaya dahil edildi. Hastaların yaş ortancası 42 (31-54); 631'i $(\% 48,7)$ kadın idi. Olguların 448'inde $(\% 34,6)$ bir veya daha fazla komplikasyon tespit edildi. Hastaların 1.125'ine $(\% 86,8)$ iki ilaç antibiyotik kombinasyonu verildi ve 171 'ine $(\% 13,2)$ üç ilaç antibiyotik kombinasyonu uygulandı. Üç yüz on altı $(\% 24,4)$ hastaya bir aminoglikozid içeren kombinasyon tedavi uygulandı. Relaps $110(\% 8,5)$ hastada meydana geldi ve tüm hastaların 105 'inde $(\% 8,1)$ tedavi yetersizdi. Osteoartiküler komplikasyonlar nüks olanlarda nüks olmayanlara göre daha sık bulunmuştur (\%33,6-18,5, p<0,001). Bruselloz olgularında osteoartiküler komplikasyon varlığının [odds oranı (OR): 2,413 güven aralığı (CI): 95; 1,550-3,756] ve uygunsuz tedavi süresinin [OR: 2,861 (Cl: 1,645-4,974)] relaps enfeksiyon gelişimini artırdığı, aminoglikozid içeren tedavi kombinasyonlarının [OR: 0,432 (Cl: 0,249-0,752)] ise relaps gelişimini azalttığı tespit edildi.

Sonuç: Sonuçlarımız osteoartiküler komplikasyonları olan hastalarda tedavinin önerilen optimal süre boyunca uygulanması gerektiğini ve enfeksiyonda relaps gelişimini önlemek için aminoglikozidleri içeren kombinasyon tedavilerinin tercih edilmesi gerektiğini göstermektedir.

Anahtar Kelimeler: Yetersiz tedavi, bruselloz, osteoartiküler tutulum, relaps

\section{Introduction}

Brucellosis is a systemic disease that can manifest along a highly heterogeneous clinical spectrum and involve many different organs in humans ${ }^{[1]}$.The goal of treatment in brucellosis is to control symptoms toprevent the development of complications and relapse of infection ${ }^{[2]}$. Relapse, defined as Brucella culture positivity and/or recurrence of disease signs and symptoms after termination of treatment, occurs in about $5-30 \%$ of cases $^{[2,3]}$. There are many studies evaluating the influence of combination therapies and treatment duration on brucellosis relapse rates. Most of these studies were conducted to determine the optimal combination therapy and treatment duration for uncomplicated cases $^{[2-5]}$. However, there are few studies evaluating the relationship between complications and infection relapse $\mathrm{e}^{[2,6]}$. The aim of this study was to evaluate the risk factors for relapse in brucellosis patients, including those with complications.

\section{Materials and Methods}

The study was conducted by retrospectively evaluating records from the infectious disease inpatient units and outpatient clinics of Erzurum Training and Research Hospital, Gaziantep Dr. Ersin Arslan Training and Research Hospital, and Mardin State Hospital. As it was a retrospective, cross-sectional study that did not constitute an additional risk to the patient, additional ethics committee approval was waived. The demographic data, laboratory results, radiological examination records, electronic prescription information, and follow-up records of patients who were registered in the hospital computer database with a brucellosis diagnostic code (International Statistical Classification of Diseases and Related Health Problems $=$ ICD codes; A23.0, A23.1, A23.2, A23.3, A23.4, A23.8, A23.9) between January 1, 2013 and December 31, 2016 were included in the study. The patients were grouped as those who had relapse and those who did not, and the groups were compared in terms of demographic data, laboratory findings at the time of initial diagnosis, and treatment approaches and durations. Those who matched the ICD code but did not meet the diagnostic criteria and patients under the age of 18 were excluded.

\section{Definitions}

Brucellosis was defined as the presence of microbiological evidence together with clinical signs and symptoms. Patients who met at least one of the following criteria were included in the study ${ }^{[4,7]}$ :

1. Isolation of Brucella spp. in sterile body fluids,

2. Titer $\geq 1 / 160$ inaBrucella standard tube agglutination test (SAT),

3. Titer $\geq 1 / 320$ in a Brucella tube agglutination with Coombs,

4. A minnimum 4-fold increase in SAT titer in serial tests performed two-three weeks apart.

The Cromatest (Linear chemicals, Spain) kit for Brucella SAT, and the Metser (Metserlab, İstanbul) Coombs Brucella test kit for Brucella Coombs gel test were used. Brucella immunoglobulin G $(\lg G)$ and $\lg M$ antibody concentrations were tested with ELISA kits from VirCell (VirCell, Spain). The BACTEC ${ }^{\text {тм }}$ FX (BD, United States) blood culture system for detecting Brucella bacteremia within the routine 1-week incubation period was used. Twomercaptoethanol was not used in the diagnosis of brucellosis. Brucella species were not defined according to subtypes, and bone marrow culture was not performed.

Complication: Defined as clinical or physical examination findings associated with disease involvement of specific anatomical regions and laboratory or radiological evidence thereof.

Osteoarticular complication: Defined as the detection of inflammation in one or more vertebrae $( \pm$ discs) or in the joint region by radiological or/and scintigraphic methods ${ }^{[4,8]}$.

Hematopoietic complication: In the absence of any other describable etiology, a platelet count $<150.000 \mathrm{IU} / \mathrm{ml}$ was accepted as thrombocytopenia, a leukocyte count $<4000 \mathrm{IU} /$ 
$\mathrm{ml}$ as leukopenia, and a hemoglobin level $<12 \mathrm{~g} / \mathrm{dl}$ in females and $<13 \mathrm{~g} / \mathrm{dl}$ in males as anemia. The detection of all three of these findings (anemia, leukopenia, and thrombocytopenia) was considered pancytopenia, and the presence of any two of them was considered bicytopenia ${ }^{[7]}$.

Hepatobiliary complication: In the absence of any other identifiable etiology, aspartate aminotransferase (AST) and alanine aminotransferase (ALT) levels $>5$ times the normal value (NV) were accepted as hepatitis, while alkaline phosphatase (ALP) level $\geq 1.5$ times the NV, gamma-glutamyl transferase (GGT) level $\geq 3$ times the NV, or total bilirubin values $>2 \mathrm{mg} / \mathrm{dl}$ was considered cholestasis. In radiologic evaluation examination (abdominal ultrasonography or computed tomography), liver size $>16 \mathrm{~cm}$ (in the midclavicular line) and spleen size $>13 \mathrm{~cm}$ were assessed as hepatomegaly and splenomegaly, respectively ${ }^{[7,9]}$.

Genitourinary complication: Detection of testicular-epididymal pain and positive ultrasonography findings (epididymis with an enlarged, hypoechoic heterogeneous appearance, abscess formation, and bilateral involvement) were accepted as epididymo-orchitis ${ }^{[7,10,11]}$.

Neurological complication (neurobrucellosis): Defined as the presence of neurological symptoms together with Brucella SAT positivity at any titer or the isolation of Brucella spp. in cerebrospinal fluid.

Cardiac complication: Cardiac complications of brucellosis include endocarditis, myocarditis, pericarditis, and pancarditis. Endocarditis is the most common cardiovascular complication. The definitive diagnostic criteria for brucella endocarditis were defined according to Duke's criteria ${ }^{[12,13]}$.

Relapse: Inpatients diagnosed with and treated for brucellosis, relapse was defined as the recurrence of symptoms and signs associated with brucellosis and at least one of the following findings at least six months after termination of treatment ${ }^{[2,8]}$ :

- Increase in SAT titer that was previously reduced with treatment,

- Repeat of Brucellaspp. isolation in sterile body fluids.

Inadequate treatment duration: Defined as treatment duration of less than eight weeks in patients with osteoarticular complications and less than six weeks in other brucellosis conditions $^{[14]}$.

\section{Statistical Analysis}

The SPSS version 20 software package was used for statistical analyses. The Kolmogorov-Smirnov test was used to test the conformity of continuous variables to normal distribution. Comparisons of two independent groups were made using Mann-Whitney U test for non-normally distributed variables. Relationships between categorical variables were tested with chi-square analysis. Univariate analyses were performed first for groups of patients with and without relapse. Multivariate analysis was then performed on variables with a significance level below 0.20 . Multivariate logistic regression was used as the analysis method. The logistic regression model included variables that were believed to influence the development of relapse and showed significant differences between groups: sex, the presence of osteoarticular complications, inadequate treatment, treatment combinations, and leukocyte white blood cells (WBC) (cut off point $=4000 \mathrm{IU} / \mathrm{ml}$ ) count. Although a significant difference in treatment duration was detected in univariate analysis, it was not included in the model due to its correlation with treatment inadequacy. Descriptive statistics were expressed as frequencies, percentages (\%) and median (25-75 percentiles). Multicollinearity was measured by variance inflation factors (VIF) and tolerance. VIF values were less than 3.0 and tolerance more than 0.2 , so there was no problem with multicollinearity. A p value of $<0.05$ was regarded as statistically significant.

\section{Results}

A total of 1,296 patients were included in the study. The median age of the patients was 42 (31-54) years; 631 (48.7\%) patients were female and 665 (51.3\%) were male. Of these, 963 patients (74.3\%) had positive Brucella SAT results $(\geq 1 / 160)$ and 1,081 (83.4\%) had positive Brucella Coombs gel test results $(\geq 1 / 320)$. Of the patients with $<1 / 160$ titers in the Brucella SAT, 331 (25.5\%) tested positive in the Brucella tube agglutination with Coombs. Brucella was isolated in the blood cultures of 13 patients (1.0\%). However, blood culture was applied to only 76 (5.8\%) of our patients. Brucella was isolated in 13/76 (17.1\%) patients in whom blood cultures were performed. One patient was diagnosed by positive blood culture despite negative tube agglutination test results. Brucella canis was isolated from the blood culture in this case. Brucella antibodies were studied by ELISA only in 209 (16.1\%) of the patients, and all of them were positive for $\lg \mathrm{M}$ and/or $\lg \mathrm{G}$ antibodies.

One or more complications were detected in 448 (34.6\%) of the cases. Osteoarticular complications occurred in 258 (19.8\%), hematopoietic in 159 (12.3\%), hepatobiliary in 96 (7.4\%), genitourinary in $19(1.5 \%)$, cardiac in one $(0.07 \%)$, and neurological in one $(0.07 \%)$ cases. In order to detect osteoarticular complications, bone scintigraphy was performed in $16(6.2 \%)$ and spinal magnetic resonance imaging in254 $(98.4 \%)$ cases. None of the patients died. The distribution of complications is presented in Table 1.

The distribution of antibiotic combinations is presented in Table 2. Gentamicin was not the preferred drug because streptomycin was in habitual use in brucellosis treatment,and it was used intramuscularly once a day, which facilitated drug 
administration. Treatment duration was less than six weeks for 72 (5.6\%) patients, six weeks for 622 (48.0\%), and over six weeks for 602 (46.5\%) patients. Treatment duration was longer in patients with complications (median: 70 days, range: 56-84 days) compared with uncomplicated cases (median: 42 days, range: $42-56)(p<0.001)$. Treatment duration was inadequate for $105(8.1 \%)$ of the patients.

Relapse occurred in 110 (8.5\%) patients. In blood culture, which wasobtained from only two of the patients who developed relapse, there was no growth of Brucella. Relapse developed after a mean of $572.7 \pm 358.6$ days and a median of 468 (1892254) days. A comparison of patients with and without relapse in terms of demographic features, the presence of complications, and laboratory parameters at the time of diagnosis is shown in Table 3 . The number of patients receiving treatment between six weeks and three months was 629 (48.5\%), 477 (36.8\%) of received treatment for three months to six months, and 88 $(6.6 \%)$ received treatment for more than 6 months.

Data obtained from the multivariate logistic regression model evaluating risk factors in terms of relapse development are given

Table 1. Distributions of complication in brucellosis

\begin{tabular}{l|l}
\hline Complication distributions & $\mathbf{n}(\%)$ \\
\hline Osteoarticular complications & $256(19.8)$ \\
\hline Spondylitis & $51(19.8)$ \\
\hline Spondylitis + Psoas abscess & $4(1.6)$ \\
\hline Spondylitis + sacroiliitis & $11(4.3)$ \\
\hline Bilateral sacroiliitis & $122(47.2)$ \\
\hline Unilateral sacroiliitis & $51(19.7)$ \\
\hline Knee involvement + bilateral sacroiliitis & $2(0.8)$ \\
\hline Knee involvement & $16(6.2)$ \\
\hline Shoulder involvement & $1(0.4)$ \\
\hline Hematopoietic complications & $159(12.3)$ \\
\hline Anemia & $42(26.4)$ \\
\hline Leukopenia & $16(10.0)$ \\
\hline Thrombocytopenia & $52(32.7)$ \\
\hline Bicytopenia & $28(17.6)$ \\
\hline Pancytopenia & $21(13.2)$ \\
\hline Hepatobiliary complication & $96(7.4)$ \\
\hline ALT >5 times the NV & $15(15.6)$ \\
\hline Total bilirubin >2 mg/dl & $3(3.1)$ \\
\hline ALP $\geq 1.5$ times the NV or GGT $\geq 3$ times the NV & $8(8.3)$ \\
\hline Hepatomegaly or splenomegaly & $70(72.9)$ \\
\hline Genitourinary complications & $19(1.5)$ \\
\hline Cardiac complications & $1(0.07)$ \\
\hline Neurological complications & $1(0.07)$ \\
\hline SV: Noma & $p h 05 h a s e$ \\
\hline
\end{tabular}

NV: Normal value, ALT: Alanine aminotransferase, ALP: Alkaline phosphatase, GGT: Gamma-glutamyl transferase in Table 4. The presence of osteoarticular complications [odds ratio (OR): 2.413, 95\% confidence interval (CI): 1.550-3.756] and inadequate treatment duration (OR: 2.861, 95\% Cl: $1.645-$ 4.974) were associated with a higher rate of brucellosis relapse, while combination therapies including an aminoglycoside (OR: $0.432,95 \% \mathrm{Cl}: 0.249-0.752)$ was associated with a lower rate.

\section{Discussion}

The relapse rate in patients with brucellosis varies between $2.4 \%$ and $29.0 \% 0^{[2,3,5,6,15-17]}$. The relapse rate in our study was $8.5 \%$, which is consistent with the literature data. It has been shown thatthetotal treatment duration in particular is a determining factor for infection relapse and that short-term treatment approaches ( $\leq 1$ month) increases the relapse rate independent of the combination therapy used ${ }^{[3-5]}$. Sofian et al. ${ }^{[18]}$ showed in a randomized controlled trial that extending treatment beyond six weeks does not affect the development of infection relapse in uncomplicated cases. The World Health Organization (WHO) recommends six weeks of treatment for uncomplicated brucellosis and at least eight weeks of treatment in patients with osteoarticular complications ${ }^{[14]}$. However, there is no consensus in the literature regarding the optimal treatment approach for complicated cases. In a study carried out by Kayaaslan et al. ${ }^{[8]}$, treatment duration for brucellosis patients with osteoarticular involvement ranged between four and six months. In a study by Kaptan et al. ${ }^{[19]}$, patients with Brucella spondylodiscitis underwent treatment for 12-39 weeks. It has been reported that continuation of treatment for 24 weeks or longer can provide effective treatment for patients with spondylodiscitis ${ }^{[20]}$. However, in our study, the effect of treatment prolongation after three months of treatment in patients with osteoarticular complications on relapse was not detected. In a 16-year prospective study examining the risk factors of recurrence in Brucellosis patients, "less effective" antibiotic therapy was found to be an independent risk factor for relapse. Treatment periods (in the same treatment regimens) were observed to be

Table 2. Distribution of antibiotic combinations

\begin{tabular}{l|l}
\hline Antibiotic combination & $\mathbf{n}(\mathbf{\%})$ \\
\hline Two-drug antibiotic combination & $1125(\mathbf{8 6 . 8 )}$ \\
\hline Doxycycline + rifampicin (DR) & $930(71.8)$ \\
\hline Doxycycline + streptomycin (DS) & $161(12.4)$ \\
\hline Doxycycline + ciprofloxacin (DC) & $15(1.2)$ \\
\hline Other Combinations & $19(1.4)$ \\
\hline Three-drug antibiotic combination & $171(13.2)$ \\
\hline Doxycycline + rifampicin + streptomycin (DRS) & $150(11.6)$ \\
\hline Doxycycline + rifampicin + ciprofloxacin (DRC) & $9(0.7)$ \\
\hline Doxycycline + streptomycin + ciprofloxacin (DSC) & $5(0.4)$ \\
\hline Other combinations & $7(0.6)$
\end{tabular}


Table 3. Comparison of brucellosis patients with and without relapse

\begin{tabular}{|c|c|c|c|}
\hline Characteristic & Relapse $(+)(n=110)$ & Relapse (-) $(n=1186)$ & $p$ value \\
\hline Age, years & $46.0(33-55)$ & $42.0(30-53)$ & $0.086^{*}$ \\
\hline Female & $52(47.3 \%)$ & $579(48.8 \%)$ & $0.756^{* *}$ \\
\hline Complications & $52(47.3 \%)$ & $396(33.4 \%)$ & $0.003^{* *}$ \\
\hline Osteoarticular complications & $37(33.6 \%)$ & $220(18.5 \%)$ & $<0.001^{* *}$ \\
\hline Hematopoietic complications & $11(10.0 \%)$ & $148(12.5 \%)$ & $0.448^{* *}$ \\
\hline Hepatobiliary complications & $11(10.0 \%)$ & $85(7.2 \%)$ & $0.278^{* *}$ \\
\hline Genitourinary complications & $1(0.9 \%)$ & $19(1.6 \%)$ & $0.587^{* *}$ \\
\hline \multicolumn{4}{|l|}{ Treatment } \\
\hline Osteoarticular complications and 3 to 6 -month treatment duration & $12(10.9 \%)$ & $102(86.0 \%)$ & $0.420^{* *}$ \\
\hline Osteoarticular complications and $>6$-month treatment duration & $3(0.2 \%)$ & $23(19.3 \%)$ & \\
\hline$A G$ & $17(15.5 \%)$ & $299(25.2 \%)$ & $0.023^{* *}$ \\
\hline Non-AG & $93(84.5 \%)$ & $839(74.8 \%)$ & \\
\hline Non-AG (2-drug combination) & $91(9.4 \%)$ & $873(90.6 \%)$ & $0.025^{* *}$ \\
\hline AG (3-drug combination) & $7(4.5 \%)$ & $148(95.5 \%)$ & \\
\hline \multicolumn{4}{|l|}{ Combination therapy } \\
\hline 2-drug combination therapy & $98(89.1 \%)$ & $1027(86.6 \%)$ & $0.459^{* *}$ \\
\hline 3-drug combination therapy & $12(10.9 \%)$ & $159(13.4 \%)$ & \\
\hline Treatment duration ${ }^{* * *}$ (day) & $42(42-70)^{*}$ & $56(42-84)^{*}$ & $0.021^{*}$ \\
\hline Inappropriate treatment & $20(19.0 \%)$ & $90(7.6 \%)$ & $<0.001^{* *}$ \\
\hline WBC $\left(10^{3} / \mathrm{L}\right)$ & $6415(5412-7825)$ & $6800(5699-8202)$ & $0.090^{*}$ \\
\hline $\mathrm{HGB}(\mathrm{g} / \mathrm{dL})$ & $14.6(13.1-15.4)$ & $14.3(13.3-15.4)$ & $0.570^{*}$ \\
\hline $\operatorname{PLT}\left(10^{3} / \mathrm{L}\right)$ & 253250 (203500-289000) & 254050 (206000-309975) & $0.302^{*}$ \\
\hline $\operatorname{ALT}(\mathrm{U} / \mathrm{L})$ & $22(16-35)$ & $22(17-389)$ & $0.641^{*}$ \\
\hline AST (U/L) & $23(18-37)$ & $23(18-34)$ & $0.574^{*}$ \\
\hline Creatinine (mg/dL) & $0.7(0.6-0.8)$ & $0.7(0.6-0.8)$ & $0.730^{*}$ \\
\hline $\mathrm{CRP}(\mathrm{mg} / \mathrm{dL})$ & $4.0(3.0-13.5)$ & $5(3.0-19.0)$ & $0.339^{*}$ \\
\hline Erythrocyte sedimentation rate (h) & $12.5(5.0-23.5)$ & $12.0(4.0-25.0)$ & $0.582^{*}$ \\
\hline
\end{tabular}

${ }^{*}$ Mann-Whitney U test, ${ }^{* *}$ Chi-square test, ${ }^{* *}$ Median $\left(25^{\text {th }}-75^{\text {th }}\right.$ percentile $)$

AG: Aminoglycoside, Non-AG: Non-aminoglycoside, WBC: White blood cells, HGB: Hemoglobin, ALT: Alanine aminotransferase, AST: Aspartate aminotransferase, PLT: Platelet, CRP: C-reactive protein.

Non-AG (2-drug combination):Used brucella effective two drug combination but not AG; AG (3-drug combination) aminoglycoside-containing brucella effective combination of three drugs

Table 4. Logistic regression model based on relapse development

\begin{tabular}{l|l|l|l|l|l}
\hline & B & S.E. & Significance (p) & OR & $\mathbf{9 5 \%}$ Cl \\
\hline Gender (male) & 0.141 & 0.204 & 0.49 & 1.151 & $0.720-1.718$ \\
\hline Combination therapy with AG & -0.838 & 0.282 & 0.003 & 0.432 & $0.249-0.752$ \\
\hline Patients with inadequate treatment & 1.051 & 0.282 & 0.001 & 2.861 & $1.645-4.974$ \\
\hline Patients with osteoarticular complications & 0.881 & 0.226 & 0.001 & 2.413 & $1.550-3.756$ \\
\hline WBC $\left(<400010^{3} / \mathrm{L}\right)$ & 0.001 & 0.001 & 0.106 & 1.000 & $1.000-1.000$ \\
\hline
\end{tabular}

AG: Aminoglycoside, WBC: White blood cells, B: $x x x x x x x$, S.E.: Standard error, OR: Odds ratio, Cl: Confidence interval

shorter in the less effective group ${ }^{[21]}$. Similarly, in our study, treatment inadequacy was defined according to the treatment durations recommended by the $\mathrm{WHO}$, and short-term treatment was associated with a 2.86 -fold higher relapse rate.
In the study performed by Ariza et al. ${ }^{[21]}, 41$ of 131 patients in the group defined as the group receiving less effective treatment had a short treatment period (30 days). This was associated with relapse. In this study with 530 patients, the incidence of inappropriate treatment time was 7.7\%. In our study, this 
frequency was found to be $8.4 \%(110 / 1296)$. This was because patients living in the regions where the study was conducted did not apply to the hospital for further treatment.

In addition to the treatment duration, the drugs used and their combinations also had a direct effect on the rate of infection relapse. In November 2006, a consensus meeting aimed at reaching a common specialist statement on the treatment of brucellosis was held in Ioannina. The antibiotic regimen containing aminoglycoside was considered as the gold standard for treatment ${ }^{[22]}$. There are also studies showing that aminoglycoside combination therapies reduced the rate of relapse ${ }^{[2,5,23]}$. A Cochrane meta-analysis published in 2012 showed that doxycycline and streptomycin combination therapy was associated with a lower rate of treatment failure and infection relapse compared with doxycycline and rifampicin therapy ${ }^{[24]}$. The results of a meta-analysis by Meng et al. ${ }^{[25]}$ demonstrated that compared with streptomycin, a rifampicin combination in patients receiving doxycycline back-bone therapy was associated with a higher rate of treatment failure and relapse. The Ministry of Health's action plan of zoonotic diseases emphasized that the combination of streptomycin and doxycycline had a lower relapse rate than the combination without streptomycin ${ }^{[26]}$. Similarly, patients in our study treated with aminoglycoside combination therapies (independent of the other agents in the combination) had a lower relapse rate.

There are few studies in the literature evaluating the relationship between complications and brucellosis relapse. Aygen et al. ${ }^{[6]}$ detected no significant relationship between relapse and the development of complications. Similarly, in a retrospective study of 980 cases of brucellosis, Roushan et al. ${ }^{[2]}$ observed no relationship between the presence of complications and relapse. Contrary to the data in the literature, our results showed that the presence of osteoarticular complications was associated with a 2.4-fold higher relapse rate. Osteoarticular involvement was the only complication significantly associated with relapse.

Although complications vary in frequency, site of involvement, and presentation, osteoarticular complications are reported to be the most common type of complication in patients with brucellosis ${ }^{[8,14,27]}$. In a systematic review evaluating Brucellosis patients in Turkey, Calik and Gokengin ${ }^{[1]}$ reported the rate of osteoarticular complications to be $43.74 \%(n=1839)$. Kayaaslan et al. ${ }^{[8]}$ determined the rate of osteoarticular complications as $22 \%$ in a study including 700 patients. At a rate of 19.8\%, osteoarticular complications were also the most common in our study.

Independent risk factors that increase the risk of relapse, such as initial symptoms (such as fever $>38{ }^{\circ} \mathrm{C}$ ) and duration of symptoms before therapy have been reported in the literature. Also, blood culture positivity, which may cause more aggressive disease, is an independent risk factor for relapse. Blood culture positivity sometimes occurs before symptoms. The prolongation of the period between the development of the disease and the onset of treatment decreases the frequency of blood culture positivity ${ }^{[21,28]}$. In addition, focal complications, due to the low number of Brucella in the blood, may limit the detection of relapse cases ${ }^{[22]}$. On the other hand, it is possible to diagnose false-positive relapses with antibody tests that are positive for a long time. In such cases, diagnosis of relapse brucellosis by polymerase chain reaction assay can be promising ${ }^{[30]}$. In our study, the relapse status of the initial findings were questioned then recorded as present or absent. However, the initial symptoms of all brucellosis patients were not recorded in detail. Therefore, the relationship between initial symptoms and relapse could not be investigated. This is the most important limitation of our study.

\section{Conclusion}

In conclusion, brucellosis patients must be evaluated carefully for the development of osteoarticular complications because these are the most common complications, the optimal treatment duration is not clear, and they are associated with an increased risk of relapse. Our results indicate that in patients with osteoarticular complications, treatment should be administered for the recommended optimal duration, and combination therapies including aminoglycosides should be selected in order to prevent infection relapse.

Ethics

Ethics Committee Approval: The ethics committee approval was not received. Because the article is retrospective.

Informed Consent: Retrospective study.

Peer-review: Externally and internallypeer-reviewed.

\section{Authorship Contributions}

Surgical and Medical Practices: Y.Y., Ö.K., H.S.Ö., Concept: M.D., Design: M.D., H.S.Ö., Data Collection or Processing: H.S.Ö., Ö.K., Y.Y., Analysis or Interpretation: H.S.Ö., Literature Search: H.S.Ö., Ö.K., Writing: H.S.Ö., Ö.K.

Conflict of Interest: No conflict of interest was declared by the authors.

Financial Disclosure: The authors declared that this study received no financial support.

\section{References}

1. Calik S, Gokengin AD. Human brucellosis in Turkey: a review of the literature between 1990 and 2009. Turk J Med Sci. 2011;41:549-55.

2. Roushan MR, Amiri MJ, Janmohammadi N, Hadad MS, Javanian M, Baiani M, Bijani A. Comparison of the efficacy of gentamicin for 5 days plus 
doxycycline for 8 weeks versus streptomycin for 2 weeks plus doxycycline for 45 days in the treatment of human brucellosis: a randomized clinical trial. J Antimicrob Chemother. 2010;65:1028-35.

3. Solera J, Geijo P, Largo J, Rodriguez-Zapata M, Gijon J, Martinez-Alfaro E, Navarro E, Macia MA, Grupo de Estudio de Castilla-la Mancha de Enfermedades I. A randomized, double-blind study to assess the optimal duration of doxycycline treatment for human brucellosis. Clin Infect Dis. 2004;39:1776-82.

4. Ulu-Kilic A, Karakas A, Erdem H, Turker T, Inal AS, Ak O, Turan H, Kazak E, Inan $A$, Duygu $F$, Demiraslan $H$, Kader $C$, Sener $A$, Dayan $S$, Deveci $O$, Tekin R, Saltoglu N, Aydin M, Horasan ES, Gul HC, Ceylan B, Kadanali A, Karabay O, Karagoz G, Kayabas U, Turhan V, Engin D, Gulsun S, Elaldi N, Alabay S. Update on treatment options for spinal brucellosis. Clin Microbiol Infect. 2014;20:75-82.

5. Solis García del Pozo J, Solera J. Systematic review and meta-analysis of randomized clinical trials in the treatment of human brucellosis. PLoS One. 2012;7:e32090.

6. Aygen B, Doganay $M$, Sumerkan B, Yildiz O, Kayabas U. Clinical manifestations, complications and treatment of brucellosis: a retrospective evaluation of 480 patients. Med Maladies Infect. 2002;32:485-93.

7. Young EJ. Brucella Species. In: Mandell GL BJ, Dolin R, eds. Mandell, Douglas, and Bennett's. Principles and Practice of Infectious Diseases. $7^{\text {th }}$ ed. Philadelphia: Churchill Livingstone Elsevier. 2010:2921-5.

8. Kayaaslan B, Bastug A, Aydin E, Akinci E, But A, Aslaner H, Yetkin MA, Bodur $\mathrm{H}$. A long-term survey of brucellosis: Is there any marker to predict the complicated cases? Infect Dis (Lond). 2016;48:215-21.

9. Ozturk-Engin D, Erdem $H$, Gencer $S$, Kaya $S$, Baran Al, Batirel A, Tekin R, Celen MK, Denk A, Guler S, Ulug M, Turan H, Pekok AU, Mermut G, Kaya S, Tasbakan M, Tulek N, Cag Y, Inan A, Yalci A, Ataman-Hatipoglu C, Gonen I, Dogan-Celik A, Bozkurt F, Gulsun S, Sunnetcioglu M, Guven T, Duygu F, Parlak E, Sozen H, Tosun S, Demirdal T, Guclu E, Karabay O, Uzun N, Gunal 0, Diktas H, Haykir-Solay A, Erbay A, Kader C, Aydin O, Erdem A, Elaldi N, Kadanali A, Yulugkural Z, Gorenek L, Altindis M, Bolukcu S, Agalar C, Ormeci $\mathrm{N}$. Liver involvement in patients with brucellosis: results of the Marmara study. Eur J Clin Microbiol Infect Dis. 2014;33:1253-62.

10. Erdem $H$, Elaldi $N, A k O$, Gulsun $S$, Tekin $R$, Ulug M, Duygu F, Sunnetcioglu M, Tulek N, Guler S, Cag Y, Kaya S, Turker N, Parlak E, Demirdal T, Ataman Hatipoglu C, Avci A, Bulut C, Avci M, Pekok A, Savasci U, Kaya S, Sozen H, Tasbakan M, Guven T, Bolukcu S, Cesur S, Sahin-Horasan E, Kazak E, Denk A, Gonen I, Karagoz G, Haykir Solay A, Alici O, Kader C, Senturk G, Tosun $S$, Turan $H$, Baran Al, Ozturk-Engin D, Bozkurt F, Deveci O, Inan A, Kadanali A, Sayar MS, Cetin B, Yemisen M, Naz H, Gorenek L, Agalar C. Genitourinary brucellosis: results of a multicentric study. Clin Microbiol Infect. 2014;20:847-53.

11. Baykan AH, Sayiner HS, Inan I. Brucella and non-Brucella epididymoorchitis: comparison of ultrasound findings. Med Ultrason. 2019;21:246-50.

12. Durack DT, Lukes AS, Bright DK. New criteria for diagnosis of infective endocarditis: utilization of specific echocardiographic findings. Duke Endocarditis Service. Am J Med. 1994;96:200-9.

13. Gul HC, Erdem H. Brucellosis (brucella species). Mandell, Douglas, and Bennett's Principles and Practice of Infectious Diseases: Elsevier. 2015:25849.e3.

14. Corbel MJ. Brucellosis in humans and animals. World Health Organization. 2006.
15. Kazak E, Akalin H, Ylimaz E, Heper Y, Mistiki R, Sinirtas M, Ozakin C, Goral G, Helvaci S. Brucellosis: a retrospective evaluation of 164 cases. Singap Med J. 2016;57:624-9.

16. Hasanain A, Mahdy R, Mohamed A, Ali M. A randomized, comparative study of dual therapy (doxycycline-rifampin) versus triple therapy (doxycyclinerifampin-levofloxacin) for treating acute/subacute brucellosis. Braz J Infect Dis. 2016;20:250-4.

17. Bosilkovski M, Zezoski M, Siskova D, Miskova S, Kotevska V, Labacevski $\mathrm{N}$. Clinical characteristics of human brucellosis in patients with various monoarticular involvements. Clin Rheumatol. 2016;35:2579-84.

18. Sofian $M$, Velayati $A A$, Aghakhani $A$, McFarland $W$, Farazi AA, Banifazl M, Eslamifar A, Ramezani A. Comparison of two durations of tripledrug therapy in patients with uncomplicated brucellosis: A randomized controlled trial. Scand J Infect Dis. 2014;46:573-7.

19. Kaptan F, Gulduren HM, Sarsilmaz A, Sucu HK, Ural S, Vardar I, Coskun NA. Brucellar spondylodiscitis: comparison of patients with and without abscesses. Rheumatol Int. 2013;33:985-92.

20. Ioannou S, Karadima D, Pneumaticos S, Athanasiou H, Pontikis J, Zormpala A, Sipsas NV. Efficacy of prolonged antimicrobial chemotherapy for brucellar spondylodiscitis. Clin Microbiol Infec. 2011;17:756-62.

21. Ariza J, Corredoira J, Pallares R, Viladrich PF, Rufi G, Pujol M, Gudiol F. Characteristics of and risk factors for relapse of brucellosis in humans. Clin Infect Dis. 1995;20:1241-9.

22. Ariza J, Bosilkovski M, Cascio A, Colmenero JD, Corbel MJ, Falagas ME, Memish ZA, Roushan MR, Rubinstein E, Sipsas NV, Solera J, Young EJ, Pappas G; International Society of Chemotherapy; Institute of Continuing Medical Education of loannina. Perspectives for the treatment of brucellosis in the 21st century: the loannina recommendations. PLoS Med. 2007;4:e317.

23. Hashemi SH, Gachkar L, Keramat $F$, Mamani M, Hajilooi M, Janbakhsh A, Majzoobi MM, Mahjub H. Comparison of doxycycline-streptomycin, doxycycline-rifampin, and ofloxacin-rifampin in the treatment of brucellosis: a randomized clinical trial. Int J Infect Dis. 2012;16:E247-E51.

24. Yousefi-Nooraie R, Mortaz-Hejri S, Mehrani M, Sadeghipour P. Antibiotics for treating human brucellosis. Cochrane Db Syst Rev. 2012.

25. Meng $F$, Pan $X$, Tong $W$. Rifampicin versus streptomycin for brucellosis treatment in humans: A meta-analysis of randomized controlled trials. Plos One. 2018;13:e0191993.

26. Türkiye Cumhuriyeti Sağlık Bakanlığı Halk Sağlığı Genel Müdürlüğü (Doganay M, Şahin M, Topaloğlu S.) Bruselloz. Son Erişim Tarihi: 01.10.2019. Erişim adresi: https://hsgm.saglik.gov.tr/depo/birimler/zoonotik-vektorelhastaliklar-db/daire-baskanligi/eylem_plani/Zoonotik_Hastaliklar_Eylem_ Pani.pdf

27. Guler S, Kokoglu OF, Ucmak H, Gul M, Ozden S, Ozkan F. Human brucellosis in Turkey: different clinical presentations. J Infect Dev Countr. 2014;8:5818.

28. Solera J, Martinez-Alfaro E, Espinosa A, Castillejos ML, Geijo P, RodriguezZapata M. Multivariate model for predicting relapse in human brucellosis. J Infect. 1998;36:85-92.

29. Morata P, Queipo-Ortuno MI, Reguera JM, Miralles F, Lopez-Gonzalez JJ, Colmenero JD. Diagnostic yield of a PCR assay in focal complications of brucellosis. J Clin Microbiol. 2001;39:3743-6.

30. Nimri LF. Diagnosis of recent and relapsed cases of human brucellosis by PCR assay. BMC Infect Dis. 2003;3:5. 